\title{
12. GEOCHEMICAL CHARACTERISTICS OF REFRACTORY SILICATE MELT INCLUSIONS FROM LEG 140 DIABASES ${ }^{1}$
}

\author{
Kevin T.M. Johnson, ${ }^{2}$ Martin R. Fisk, ${ }^{3}$ and Howard R. Naslund ${ }^{4}$
}

\begin{abstract}
Geochemical data from plagioclase-hosted silicate melt inclusions from Leg 140, Hole 504B diabase dikes are reported. Hand-picked plagioclase grains were heated to $1260^{\circ}-1280^{\circ} \mathrm{C}$ to remelt the glass inclusions and to infer trapping temperatures. The samples were then polished to expose the inclusions, which were analyzed by electron and ion microprobes. Inclusion compositions are mainly in equilibrium with the host plagioclase and are more depleted in incompatible elements than the host rock. Simple crystal-liquid equilibrium calculations show that the melt inclusions could have been in equilibrium with depleted abyssal peridotite diopsides, whereas whole-rock basalt compositions generally could not have been. The melt inclusions are significantly more depleted than normal ( $\mathrm{N}$-type) mid-ocean-ridge basalt (MORB) and are consistent with being produced by $8 \%-16 \%$ incremental or open-system melting with $2 \%$ residual porosity in the peridotite source. These magmas were formed during pressurerelease melting of the mantle over a range of depths between 30 and $15 \mathrm{~km}$.
\end{abstract}

\section{INTRODUCTION}

In recent years, the process of mantle melting at mid-ocean ridges to produce mid-ocean-ridge basalt (MORB) has received much attention from earth scientists. Constraints on the physical melting process have come from studies of basalts (Klein and Langmuir, 1987), abyssal peridotites (Dick et al., 1984; Johnson et al., 1990; Johnson and Dick, 1992), experimental petrologic data (McKenzie and Bickle, 1988), isotopes (McKenzie, 1985; Rubin and Macdougall, 1988), and laboratory physical properties studies (Riley and Kohlstedt, 1991; Waff and Faul, 1992). Synthesizing the results of these studies, one can conclude that melting takes place over a column of mantle extending over a depth range depending on compositional and thermal conditions, that small melt fractions can segregate from their peridotite source, and that this process has profound effects on the chemistry of the melts and residues produced. The culmination of this process, variously called fractional, dynamic, incremental, and open-system melting, is that small melt fractions move through the melting column and aggregate or homogenize en route to the surface, where they are erupted as MORB. Thus, even high-Mg primitive MORB are probably not primary melts, and the search for the primary melts has led to investigations of silicate melt inclusions (Sobolev and Dmitriev, 1989; Johnson, 1990; Sobolev and Shimizu, 1993).

Interest in the chemical composition of melt inclusions stems directly from their potential role as windows into the mantle. Refractory melt inclusions with compositions that could have been in equilibrium with mantle olivine of $\mathrm{Fo}_{89-91}$ were described by a number of workers (e.g., Donaldson and Brown, 1977; Dungan and Rhodes, 1978; Sobolev and Naumov, 1985; Falloon and Green, 1986). If melting occurs over a depth range, and if minerals crystallize at any given depth(s), then they are theoretically capable of trapping melt anywhere along the ascent path. These primary melt inclusions (those fractions of melt trapped in a growing crystal as a result of some process or mechanism(s) that interrupts the growth of a perfect crystal, such as surface cracks, defects, or non-uniform growth [Roedder, 1984]) could therefore record the composition(s) of any liquids in

\footnotetext{
'Erzinger, J., Becker, K., Dick, H.J.B., and Stokking, L.B. (Eds.), 1995. Proc. ODP. Sci. Results, 137/140: College Station, TX (Ocean Drilling Program).

${ }^{2}$ Department of Natural Sciences, Bishop Museum, Honolulu, HI 96817 , U.S.A.

${ }^{3}$ College of Oceanic and Atmospheric Sciences, Oregon State University, Corvallis, OR 97331, U.S.A

${ }^{4}$ Geological Sciences, State University of New York, Binghamton, NY 13902, U.S.A.
}

which the host mineral experienced a growth phase. Thus, the working hypothesis for this study is that if sub-ridge melting is nearly fractional, then small, primary melt increments may be preserved as melt inclusions in minerals growing from the early-formed melt, leading to the prediction that melt inclusions may span a range of compositions, the average of which represents MORB.

In evaluating the composition of melt inclusions, the effect of interaction between trapped melt and host phase must be addressed. While the absolute concentrations of elements may have been affected by post-entrapment crystallization and reequilibration, the ratios of incompatible elements are unlikely to have changed significantly and therefore can be used to infer the composition of the source region. Interpretation of inclusions as primary melts requires that they be in equilibrium with mantle olivines. Satisfying this requirement alone, however, is not proof that an inclusion represents an unmodified primary melt. Post-entrapment crystallization of plagioclase could have significantly altered the melt composition without changing its $\mathrm{Mg}$ / $(\mathrm{Mg}+\mathrm{Fe})$ and thus it would appear to be in equilibrium with mantle olivine. A possible manifestation of post-entrapment crystallization would be enrichment in incompatible elements such as $\mathrm{Ti}, \mathrm{Zr}$, and the rare earth elements (REE).

In this paper, we report major and trace element compositions of silicate melt inclusions contained in plagioclase crystals from diabases recovered in Hole 504B on Ocean Drilling Program (ODP) Legs 137 and 140 (Fig. 1). From these data, we discuss their potential role as indicators of source and primary melt compositions and, in some cases, of the melting process by which they were produced.

\section{ANALYTICAL TECHNIQUES}

\section{Mineral Selection}

Five samples were chosen from Hole 504B based on the abundance of the plagioclase phenocrysts, the lack of plagioclase alteration, and representativeness of the recovered diabase types. Plagioclase was separated from the crushed rock, and about 20 grains were selected from the coarsest size fraction $(0.7-1.0 \mathrm{~mm})$ of each separation to ensure that they were phenocrysts and not groundmass plagioclase.

\section{High Temperature Microthermometry}

Five plagioclase grains were heated to between $1260^{\circ}$ and $1280^{\circ} \mathrm{C}$ for $4 \mathrm{hr}$ and then were quenched in water. This technique has been used previously to homogenize inclusions in phenocrysts (Vicenzi, 


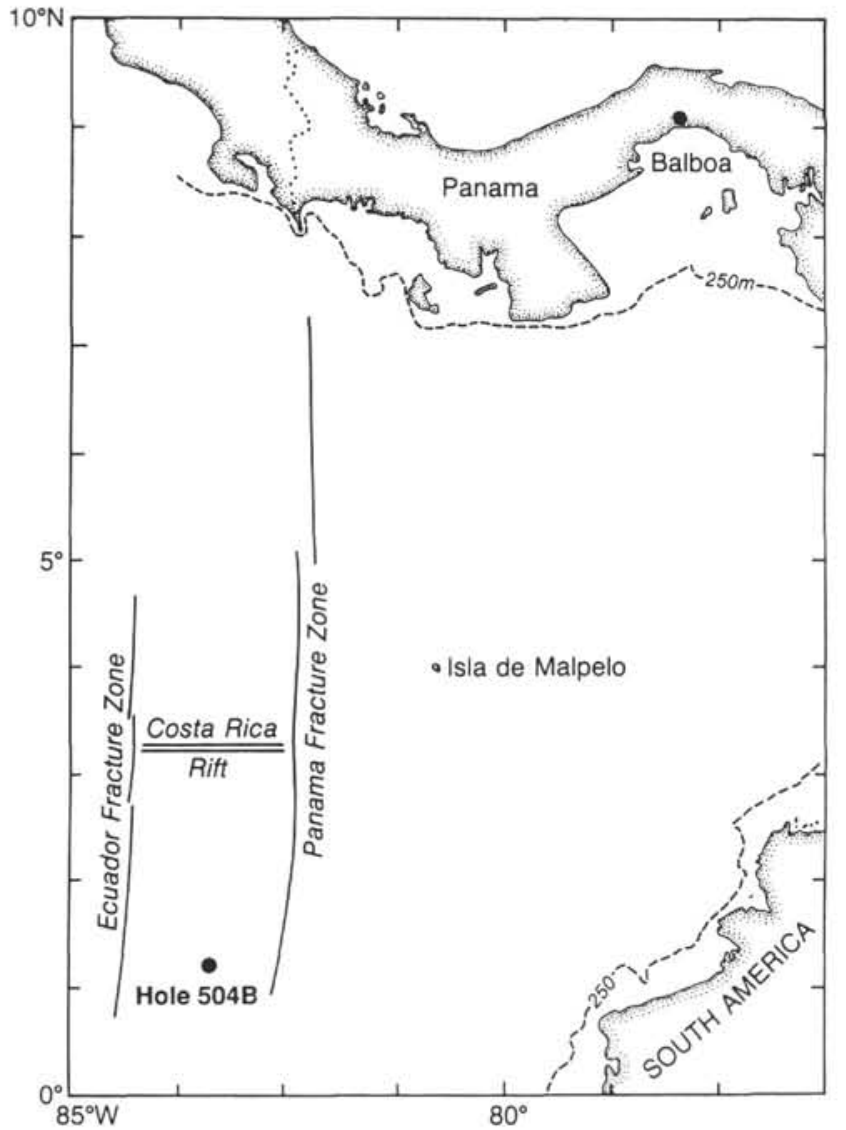

Figure 1. Location of Site 504

1985; Hansteen, 1991; Coombs et al., 1991; Sinton et al., 1993). The temperature was controlled to within $2^{\circ} \mathrm{C}$ of the indicated temperature using a Deltec vertical quench furnace, Eurotherm temperature controllers, and Pt-Pt10\%Rh thermocouples. A second thermocouple, placed less than $10 \mathrm{~mm}$ from plagioclase grains, was used to monitor their temperature. The furnace atmosphere was maintained at an oxygen fugacity similar to that experienced by the host basalts with a mixture of $\mathrm{H}_{2}$ and $\mathrm{CO}_{2}$. Table 1 lists the samples and run temperatures; abbreviations will be used throughout the text.

After the plagioclase cooled, it was mounted in epoxy, polished, and examined with the back-scattered electron detector on the microprobe (Fig. 2). In all $1270^{\circ}$ and $1280^{\circ} \mathrm{C}$ runs, the partially crystalline inclusions in the plagioclase were completely melted to form a homogenous liquid plus a gas bubble in some cases. At $1260^{\circ} \mathrm{C}$ most inclusions were completely melted, but some still contained olivine $(<1$ $\mu \mathrm{m})$. This suggests that the melts were originally trapped at $\geq 1260^{\circ} \mathrm{C}$, but less than $1270^{\circ} \mathrm{C}$. The melt inclusions and surrounding plagioclase were analyzed by ion microprobe at Woods Hole Oceanographic Institution and by electron microprobe at Oregon State University.

\section{Electron Microprobe Analyses}

All analyses were done on a Cameca SX-50 four-spectrometer microprobe at Oregon State University Electron Microprobe Laboratory. Measured concentrations were corrected for atomic number, absorption, and fluorescence effects by the ZAF method. Standards consisted of natural minerals and basalt glass from the Smithsonian reference collection (Jarosewich et al., 1980) and a commercially prepared standard block (Astimex Scientific LTD, 16 Edgewood Crescent, Toronto, Canada).

Plagioclase phenocrysts were analyzed using the following standards: Kakanui anorthoclase (USNM 133868) for Si and Na; Kakanui
Table 1. Samples and run temperatures.

\begin{tabular}{|c|c|c|c|c|c|}
\hline Abbreviation & Run \# & $\begin{array}{c}\text { Temperature } \\
\left({ }^{\circ} \mathrm{C}\right)\end{array}$ & Sample & Piece & $\begin{array}{l}\text { Lith } \\
\text { unit }\end{array}$ \\
\hline \multirow[t]{3}{*}{ HRN-3 } & 228 & $1280^{\circ}$ & $\begin{array}{l}137-504 \mathrm{~B}- \\
181 \mathrm{M}-2,109-114\end{array}$ & $9 \mathrm{~A}$ & 210 \\
\hline & $\begin{array}{l}233 \\
235\end{array}$ & $\begin{array}{l}1270^{\circ} \\
1260^{\circ}\end{array}$ & & & \\
\hline & & & 140-504B- & & \\
\hline HRN-7 & 236 & $1260^{\circ}$ & 191R-1, $34-40$ & $7 \mathrm{~A}$ & 218 \\
\hline HRN-10 & 234 & $1260^{\circ}$ & $200 \mathrm{R}-1,16-24$ & $5 \mathrm{~A}, 5 \mathrm{~B}$ & 227 \\
\hline HRN-14 & 237 & $\begin{array}{l}1260^{\circ} \\
1260^{\circ}\end{array}$ & $\begin{array}{l}205 R-1,95-102 \\
206 R-1,9-38\end{array}$ & $\begin{array}{l}23,24 \\
3,4 \mathrm{~A}, 7,9\end{array}$ & $\begin{array}{l}235 \\
235\end{array}$ \\
\hline HRN-22 & 238 & $1260^{\circ}$ & $226 \mathrm{R}-1,134-140$ & 24 & 260 \\
\hline
\end{tabular}

Note: All samples from Hole 504B.

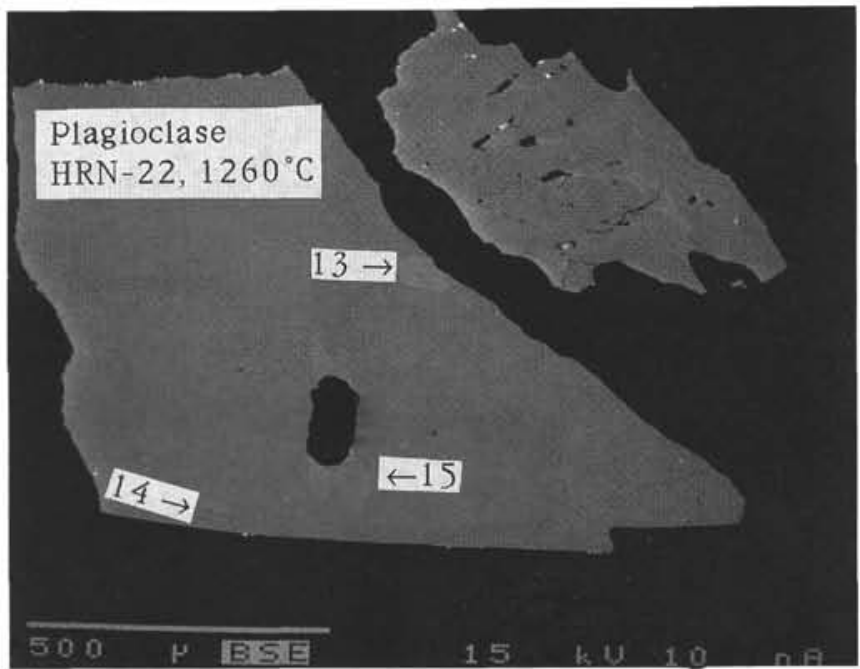

Figure 2. Back-scattered electron photograph of a representative silicate melt inclusion analyzed in this study. Epoxy, which surrounds the two plagioclase grains, and vesicles appear black. Three light gray inclusions are numbered corresponding to Tables 2,3 , and 4 . Ion probe analysis pits within the inclusion are indicated by the arrows.

augite (USNM 122142) for Fe and Mg; Lake County, OR, labradorite (USNM 115900) for Ca and $\mathrm{Al}$ (Jarosewich et al., 1980); and Hohenfels Sanidine for K. Analytical conditions were $15 \mathrm{kV}$ accelerating voltage, $30 \mathrm{nA}$ probe current, and $10 \mathrm{~s}$ counting time with a focused beam. Glasses were analyzed using the following standards: Kakanui anorthoclase for $\mathrm{Na}$; Kakanui augite for $\mathrm{Mg}$; Durango fluorapatite for $\mathrm{P}$; Hohenfels sanidine for $\mathrm{K}$; Makaopuhi basalt glass for $\mathrm{Ca}, \mathrm{Fe}, \mathrm{Al}$, $\mathrm{Ti}$, and $\mathrm{Si}$; an unknown pyroxmangite for $\mathrm{Mn}$; and Tiebaghi chromite for $\mathrm{Cr}$. Analytical conditions were $15-\mathrm{kV}$ accelerating voltage, $50-\mathrm{nA}$ beam current, defocused beam (approximately $30 \mu \mathrm{m}$ ), and $10 \mathrm{~s}$ counting times for all elements except $\mathrm{Cr}$, which was counted for 20 s. Na was always analyzed first and showed no significant loss during analysis. Precision of this technique (based on multiple analyses of the Makaopuhi basalt glass) is reported elsewhere (Forsythe and Fisk, 1993). Glass in the experiments was analyzed seven to 12 times at several different locations within the sample, and the averages of these analyses are given in Table 2 .

\section{Ion Microprobe Analyses}

All ion probe analyses were done on the Cameca IMS 3-f located at Woods Hole Oceanographic Institution. For the isotopes ${ }^{30} \mathrm{Si},{ }^{47} \mathrm{Ti}$, ${ }^{51} \mathrm{~V},{ }^{52} \mathrm{Cr},{ }^{88} \mathrm{Sr},{ }^{89} \mathrm{Y},{ }^{90} \mathrm{Zr}$, and ${ }^{93} \mathrm{Nb}$, a primary beam of negatively charged oxygen ions with a current of approximately $0.2 \mathrm{nA}$ and a net 
Table 2. Major element analyses of silicate melt inclusions in plagioclase from Legs 137 and 140 diabase, Hole 504B.

\begin{tabular}{|c|c|c|c|c|c|c|c|c|c|c|c|c|c|c|c|c|c|}
\hline Run & Sample & $\mathrm{T}^{\circ} \mathrm{C}$ & Incl.\# & Unit & $\mathrm{SiO}_{2}$ & $\mathrm{TiO}_{2}$ & $\mathrm{Al}_{2} \mathrm{O}_{3}$ & $\mathrm{FeO}$ & $\mathrm{MnO}$ & $\mathrm{MgO}$ & $\mathrm{CaO}$ & $\mathrm{Na}_{2} \mathrm{O}$ & $\mathrm{K}_{2} \mathrm{O}$ & $\mathrm{P}_{2} \mathrm{O}_{5}$ & $\mathrm{Cr}_{2} \mathrm{O}_{3}$ & Total & $\mathrm{Mg \#}$ \\
\hline OP228 & HRN-3 & 1280 & 1 & 210 & 50.80 & 0.38 & 18.80 & 7.08 & 0.14 & 8.00 & 12.70 & 1.90 & 0.09 & 0.03 & 0.06 & 99.98 & 0.668 \\
\hline OP228 & HRN-3 & 1280 & 2 & 210 & 50.50 & 0.4 & 18.40 & 7.23 & 0.12 & 7.79 & 13.40 & 1.91 & 0.02 & 0.04 & 0.10 & 99.91 & 0.658 \\
\hline OP $228^{\circ}$ & HRN-3 & 1280 & 3 & 210 & 51.20 & 0.41 & 18.10 & 7.42 & 0.18 & 7.64 & 13.00 & 1.77 & 0.02 & 0.05 & 0 & 99.79 & 0.647 \\
\hline OP 228 & HRN-3 & 1280 & 3 & 210 & 50.50 & 0.48 & 18.10 & 7.32 & 0.13 & 7.71 & 13.00 & 1.74 & 0.03 & 0.05 & 0.03 & 99.09 & 0.652 \\
\hline OP228. & HRN-3 & 1280 & 3 & 210 & 51.10 & 0.45 & 18.00 & 7.42 & 0.15 & 7.73 & 13.00 & 1.70 & 0 & 0.04 & 0.09 & 99.68 & 0.650 \\
\hline OP $228^{\circ}$ & HRN-3 & 1280 & 4 & 210 & 51.50 & 0.44 & 18.30 & 7.36 & 0.09 & 7.52 & 13.00 & 2.02 & 0.01 & 0.03 & 0.02 & 100.29 & 0.645 \\
\hline OP233. & HRN-3 & 1270 & 6 & 210 & 50.39 & 0.33 & 18.77 & 8.66 & 0.16 & 5.74 & 11.99 & 2.03 & 0.01 & 0 & 0.02 & 98.10 & 0.542 \\
\hline $\mathrm{OP} 233^{*}$ & HRN-3 & 1270 & 7 & 210 & 49.83 & 0.37 & 18.37 & 9.01 & 0.14 & 5.80 & 12.32 & 2.58 & 0.02 & 0 & 0 & 98.44 & 0.534 \\
\hline OP233 & HRN-3 & 1270 & 8 & 210 & 48.50 & 0.15 & 21.76 & 7.57 & 0.11 & 9.22 & 8.66 & 2.38 & 0.05 & 0.05 & 0 & 98.46 & 0.685 \\
\hline OP233 & HRN-3 & 1270 & 9 & 210 & 51.60 & 0.36 & 17.88 & 4.65 & 0.18 & 8.83 & 14.46 & 1.87 & 0.02 & 0 & 0.02 & 99.87 & 0.772 \\
\hline $\mathrm{OP} 233$ & HRN-3 & 1270 & 10 & 210 & 50.74 & 0.47 & 17.63 & 3.62 & 0.16 & 9.14 & 14.56 & 1.81 & 0.04 & 0.04 & 0.10 & 98.30 & 0.818 \\
\hline OP $235^{\circ}$ & HRN-3 & 1260 & 11 & 210 & 53.27 & 0.89 & 18.76 & 4.22 & 0.17 & 7.92 & 11.69 & 2.60 & 0.05 & 0.03 & 0.01 & 99.62 & 0.770 \\
\hline OP235. & HRN-3 & 1260 & 12 & 210 & 47.78 & 0.74 & 17.92 & 9.47 & 0.21 & 6.80 & 12.95 & 2.30 & 0.01 & 0 & 0.02 & 98.19 & 0.561 \\
\hline $\mathrm{OP} 236^{\circ}$ & HRN-7 & 1260 & 1 & 218 & 50.63 & 0.43 & 17.63 & 4.54 & 0.15 & 9.31 & 13.95 & 1.60 & 0.01 & 0.05 & 0.10 & 98.40 & 0.785 \\
\hline OP236 & HRN-7 & 1260 & 2 & 218 & 51.19 & 0.37 & 17.92 & 5.20 & 0.15 & 8.83 & 12.39 & 1.98 & 0.06 & 0 & 0.06 & 98.16 & 0.752 \\
\hline OP236 & HRN-7 & 1260 & 3 & 218 & 49.48 & 0.47 & 17.64 & 8.41 & 0.18 & 7.29 & 12.99 & 2.12 & 0 & 0.04 & 0.06 & 98.68 & 0.607 \\
\hline OP236 & HRN-7 & 1260 & 4 & 218 & 51.31 & 0.55 & 16.76 & 5.11 & 0.12 & 6.58 & 16.12 & 1.86 & 0.06 & 0.08 & 0.10 & 98.64 & 0.696 \\
\hline OP236 & HRN-7 & 1260 & 5 & 218 & 51.24 & 0.61 & 16.60 & 5.19 & 0.14 & 6.46 & 16.12 & 1.86 & 0.06 & 0.01 & 0.08 & 98.37 & 0.689 \\
\hline OP234. & HRN-10 & 1260 & 1 & 227 & 49.41 & 0.39 & 18.46 & 4.08 & 0.20 & 10.73 & 12.55 & 1.99 & 0.05 & 0 & 0.04 & 97.90 & 0.824 \\
\hline OP $234^{\circ}$ & HRN-10 & 1260 & 13 & 227 & 50.80 & 0.62 & 20.39 & 2.68 & 0.13 & 8.96 & 13.28 & 2.27 & 0.06 & 0.01 & 0 & 99.19 & 0.856 \\
\hline $\mathrm{OP} 237$ & HRN-14 & 1260 & 1 & 235 & 48.83 & 0.81 & 17.36 & 8.03 & 0.17 & 6.86 & 12.97 & 2.24 & 0.01 & 0.08 & 0.04 & 97.41 & 0.604 \\
\hline OP237 & HRN-14 & 1260 & 2 & 235 & 49.14 & 0.49 & 17.99 & 8.17 & 0.11 & 6.79 & 12.79 & 2.16 & 0.04 & 0.01 & 0.04 & 97.73 & 0.597 \\
\hline OP237 & HRN-14 & 1260 & 3 & 235 & 52.19 & 1.18 & 17.67 & 4.82 & 0.23 & 6.75 & 13.08 & 2.42 & 0.05 & 0.03 & 0.03 & 98.45 & 0.714 \\
\hline OP237. & HRN-14 & 1260 & 4 & 235 & 52.34 & 1.30 & 17.91 & 4.41 & 0.20 & 6.79 & 12.99 & 2.47 & 0.06 & 0.07 & 0.03 & 98.57 & 0.733 \\
\hline OP $237^{*}$ & HRN-14 & 1260 & 5 & 235 & 50.69 & 0.52 & 18.07 & 5.97 & 0.18 & 8.46 & 12.99 & 2.12 & 0.05 & 0.05 & 0.04 & 99.15 & 0.716 \\
\hline OP237 & HRN-14 & 1260 & 6 & 235 & 50.14 & 0.43 & 18.98 & 6.26 & 0.15 & 9.62 & 11.90 & 2.23 & 0.05 & 0.06 & 0.06 & 99.88 & 0.733 \\
\hline OP237 & HRN-14 & 1260 & 7 & 235 & 51.52 & 0.46 & 17.81 & 5.54 & 0.15 & 7.53 & 12.86 & 2.27 & 0.08 & 0.08 & 0.04 & 98.34 & 0.708 \\
\hline OP237 & HRN-14 & 1260 & 8 & 235 & 50.08 & 0.50 & 17.83 & 6.98 & 0.19 & 7.31 & 13.28 & 2.23 & 0.03 & 0 & 0.04 & 98.47 & 0.651 \\
\hline OP237 & HRN-14 & 1260 & 9 & 235 & 52.43 & 1.08 & 17.92 & 5.02 & 0.23 & 6.92 & 12.87 & 2.53 & 0.05 & 0.06 & 0.05 & 99.15 & 0.711 \\
\hline OP238 & HRN-22 & 1260 & 9 & 260 & 49.49 & 0.22 & 17.47 & 7.66 & 0.16 & 7.76 & 13.09 & 2.34 & 0.03 & 0.06 & 0.04 & 98.32 & 0.644 \\
\hline OP238 & HRN-22 & 1260 & 10 & 260 & 50.04 & 0.57 & 17.82 & 6.95 & 0.15 & 7.95 & 12.52 & 2.19 & 0.03 & 0.11 & 0.06 & 98.39 & 0.671 \\
\hline OP238 & HRN-22 & 1260 & 11 & 260 & 50.20 & 0.62 & 17.95 & 6.88 & 0.21 & 8.18 & 12.63 & 2.05 & 0.04 & 0.02 & 0.06 & 98.84 & 0.679 \\
\hline OP238. & HRN-22 & 1260 & 12 & 260 & 49.06 & 0.24 & 17.44 & 7.84 & 0.17 & 7.85 & 12.95 & 2.39 & 0.03 & 0 & 0.06 & 98.03 & 0.641 \\
\hline OP238. & HRN-22 & 1260 & 13 & 260 & 48.99 & 0.17 & 17.20 & 5.05 & 0.18 & 9.69 & 12.74 & 1.80 & 0.04 & 0.09 & 0.04 & 95.99 & 0.774 \\
\hline OP $238^{*}$ & HRN-22 & 1260 & 14 & 260 & 47.54 & 0.15 & 17.36 & 5.51 & 0.11 & 10.80 & 12.73 & 1.62 & 0 & 0.03 & 0.03 & 95.88 & 0.777 \\
\hline OP $238^{\circ}$ & HRN-22 & 1260 & 15 & 260 & 48.50 & 0.14 & 17.24 & 6.03 & 0.15 & 8.70 & 12.38 & 1.88 & 0.06 & 0.05 & 0.04 & 95.17 & 0.720 \\
\hline OP238 & HRN-22 & 1260 & 16 & 260 & 50.69 & 1.20 & 18.80 & 9.65 & 0.24 & 3.89 & 9.65 & 3.56 & 0.06 & 0.09 & 0.02 & 97.85 & 0.418 \\
\hline OP238 & HRN-22 & 1260 & 18 & 260 & 48.24 & 0.95 & 18.00 & 8.53 & 0.10 & 6.42 & 12.03 & 2.53 & 0.02 & 0.08 & 0.06 & 96.96 & 0.573 \\
\hline
\end{tabular}

Note: *Inclusions for which ion microprobe analyses are reported in Table 3.

energy of $12.55-12.65 \mathrm{keV}$ was focused to a spot $8-12 \mu \mathrm{m}$ in diameter. For rare earth element isotopes (REE) ${ }^{139} \mathrm{La},{ }^{140} \mathrm{Ce},{ }^{146} \mathrm{Nd},{ }^{147} \mathrm{Sm}$, ${ }^{153} \mathrm{Eu},{ }^{163} \mathrm{Dy},{ }^{167} \mathrm{Er}$, and ${ }^{174} \mathrm{Yb}$, a primary beam current of $1-2 \mathrm{nA}$ was focused to a $15-25 \mu \mathrm{m}$ spot, and a high energy offset of $-50 \mathrm{eV}$ was used. Positively charged secondary ions were mass analyzed by a double focusing mass spectrometer with a high energy offset of -90 $\mathrm{eV}$ and an energy bandpass of $\pm 10 \mathrm{eV}$ for a net secondary accelerating voltage of $4400-4420 \mathrm{eV}$, and were detected and counted by a 17-stage Allen-type electron multiplier in pulse counting mode.

Individual spot analyses included five cycles of measurements, each cycle beginning with backgrounds and stepping progressively up mass to previously located peaks. Background and deadtime corrected secondary ion intensities were normalized to either ${ }^{163} \mathrm{Dy}$, for $\mathrm{REE}$, or ${ }^{30} \mathrm{Si}$ for the other trace elements. Intensity ratios were converted to concentrations using empirically derived intensity ratioconcentration correction factors (working curves) determined from well-analyzed glass standards of similar Si composition. All glasses used as standards were previously analyzed for REE and other trace elements by isotope dilution mass spectrometry (ID) and X-ray fluorescence (XRF) (Bender et al., 1984). ${ }^{153} \mathrm{Eu}$ analyses are less accurate than other REE due to isobaric barium oxide and hydroxide molecular ion interferences (Johnson and Dick, 1992).

Uncertainties in trace element measurements by ion microprobe are a function of uncertainty in slopes of working curves and from variations in counts in individual point analyses (counting statistics). Uncertainty in the working curve slope is itself a function of ion probe counting statistics and the quality of the standard (i.e., its homogeneity and the accuracy of its composition as determined by another analytical technique). Slope uncertainty influences the accuracy of the calculated unknown concentration and is minimized by using high quality standards, replicate measurements, and consistent operating conditions. Using standards with nearly the same major element concentrations as unknowns minimizes matrix effects. Slopes for each element were calculated based on normalized silica concentration in the standard to compensate for silicon-induced bias in the intensity ratios. Slopes and uncertainties calculated for this study are 3 relative percent (r.p.) for Ti, 5 r.p.-10 r.p. for $\mathrm{V}, \mathrm{Cr}, \mathrm{Sr}, \mathrm{Y}, \mathrm{Zr}, \mathrm{Ce}, \mathrm{Nd}, \mathrm{Sm}, \mathrm{Dy}$, and Yb, 10 r.p. -15 r.p. for $\mathrm{Nb}, \mathrm{La}$, and $\mathrm{Er}$, and $>20$ r.p. for Eu. Trace element concentrations for the melt inclusions are reported in Table 3 .

\section{RESULTS}

\section{Evaluating Inclusion Compositions}

Measured inclusion compositions could have been affected by overlap of the ion beam onto plagioclase during ion probe analyses or by melting of the host plagioclase during homogenization. Extreme care was taken to avoid beam overlap onto the plagioclase. An independent assessment of the analyses' accuracy was performed by plotting the Ti contents of the inclusions as determined by both ion and electron microprobes. Ideally, data on this plot should define a slope of one. The results of this comparison are shown in Figure 3. Only inclusion 7 in $\mathrm{HRN}-3$ at $1270^{\circ} \mathrm{C}$ plots significantly off the $1: 1$ line. Assuming that the electron probe analysis is good, based on that machine's superior optical imaging capabilities, a point below the line could be caused by the ion beam overlapping onto the host mineral, causing a dilution of Ti. Another explanation could be that the inclusions are heterogeneous or contain impurities, meaning that the inclusion is not a homogeneous glass and that differences in beam placement between electron and ion probe analyses could account for compositional disagreement. However, overlap of the ion beam onto plagioclase should cause a significant increase in the measured $\mathrm{Sr}$ content, which is not observed in this sample (Fig. 4), and the cause for the discrepancy in Ti measurements is not understood.

A second test of beam overlap or plagioclase melting was applied to the samples based on the relative compatibility of $\mathrm{Sr}$ and $\mathrm{Eu}$ in 
Table 3. Trace element concentrations in Leg 137 and 140 melt inclusions (in ppm).

\begin{tabular}{|c|c|c|c|c|c|c|c|c|c|c|c|c|c|c|c|c|c|c|c|c|c|}
\hline Run & Sample & $\mathrm{T}^{\circ} \mathrm{C}$ & Incl.\# & Unit & $\mathrm{Ti}$ & V & $\mathrm{Cr}$ & $\mathrm{Sr}$ & $Y$ & $\mathrm{Zr}$ & $\mathrm{Nb}$ & $\mathrm{La}$ & $\mathrm{Ce}$ & $\mathrm{Nd}$ & $\mathrm{Sm}$ & $\mathrm{Eu}$ & Dy & $\mathrm{Er}$ & $\mathrm{Yb}$ & $\mathrm{Ti} / \mathrm{Zr}$ & $(\mathrm{La} / \mathrm{Sm})_{\mathrm{n}}$ \\
\hline OP228 & HRN-3 & 1280 & 2 & 210 & 2243 & 165 & 288 & 46.6 & 9.2 & 14 & 0.15 & 0.19 & 0.81 & 1.13 & 0.55 & 0.25 & 0.95 & 0.55 & 0.57 & 160 & 0.22 \\
\hline OP228 & HRN-3 & 1280 & 3 & 10 & 2457 & 189 & 292 & 42.5 & 10.6 & 15 & 0.23 & 0.35 & 1.21 & 2.15 & 0.94 & 0.37 & 2.03 & 0.88 & 1.06 & 164 & 0.23 \\
\hline OP228 & HRN-3 & 1280 & 4 & 210 & 2355 & 179 & 283 & 43.6 & 10.2 & 15 & 0.16 & & & & & 156 & & & & & \\
\hline OP228 & HRN-3 & 1280 & 5 & 210 & 3356 & 159 & 150 & 47.3 & 14.2 & 23 & 0.34 & 0.49 & 2.09 & 3.19 & 1.23 & 0.30 & 2.33 & 1.77 & 1.45 & 144 & 0.25 \\
\hline OP233 & HRN-3 & 1270 & 7 & 210 & 983 & 128 & 535 & 1.2 & 3.2 & 4.1 & 0.55 & 0.21 & 0.65 & 1.74 & 0.66 & 0.19 & 0.80 & 0.80 & 0.77 & 239 & 0.20 \\
\hline OP235 & HRN-3 & 1260 & 11 & 210 & 5302 & 171 & 185 & 46.8 & 20.2 & 35 & 1.77 & 0.70 & 3.26 & 4.81 & 2.34 & 0.55 & 4.29 & 2.89 & 3.07 & 152 & 0.19 \\
\hline OP236 & HRN-7 & 1260 & 1 & 218 & 2619 & 176 & 360 & 46.9 & 17.7 & 28 & 0.87 & 0.60 & 2.05 & 4.30 & 2.20 & 0.61 & 3.46 & 2.57 & 2.30 & 95 & 0.17 \\
\hline OP234 & HRN-10 & 1260 & 1 & 227 & 1888 & 134 & 247 & 93.2 & 10.1 & 13 & 1.05 & 0.42 & 2.00 & 2.93 & 1.11 & 0.80 & 2.16 & 1.37 & 1.12 & 146 & 0.24 \\
\hline OP234 & HRN-10 & 1260 & 13 & 227 & 4056 & 193 & 198 & 71.4 & 15.2 & 36 & 1.32 & 1.06 & 3.64 & 5.24 & 2.26 & 0.85 & 3.81 & 2.65 & 2.85 & 113 & 0.29 \\
\hline OP237 & HRN-14 & 1260 & 5 & 235 & 3081 & 172 & 223 & 61.3 & 13.9 & 22 & 1.30 & 0.72 & 3.15 & 4.09 & 1.74 & 0.63 & 3.3 & 1.94 & 2.16 & 142 & 0.26 \\
\hline OP238 & HRN-22 & 1260 & 13 & 260 & 1122 & 173 & 355 & 19.7 & 15.4 & 3.0 & 0.78 & 0.73 & 3.54 & 5.29 & 2.89 & 0.78 & 4.28 & 2.47 & 1.96 & 369 & 0.16 \\
\hline OP238 & HRN-22 & 1260 & 14 & 260 & 1081 & 183 & 332 & 40.1 & 10.2 & 4.0 & 0.71 & 0.12 & 0.42 & 1.10 & 0.79 & 0.19 & 1.00 & 0.64 & 0.94 & 270 & 0.10 \\
\hline OP238 & HRN-22 & 1260 & 15 & 260 & 880 & 105 & 370 & 7.9 & 3.3 & 3.3 & 0.39 & 0.54 & 1.97 & 3.11 & 1.76 & 0.80 & 2.23 & 1.55 & 1.66 & 269 & 0.19 \\
\hline
\end{tabular}

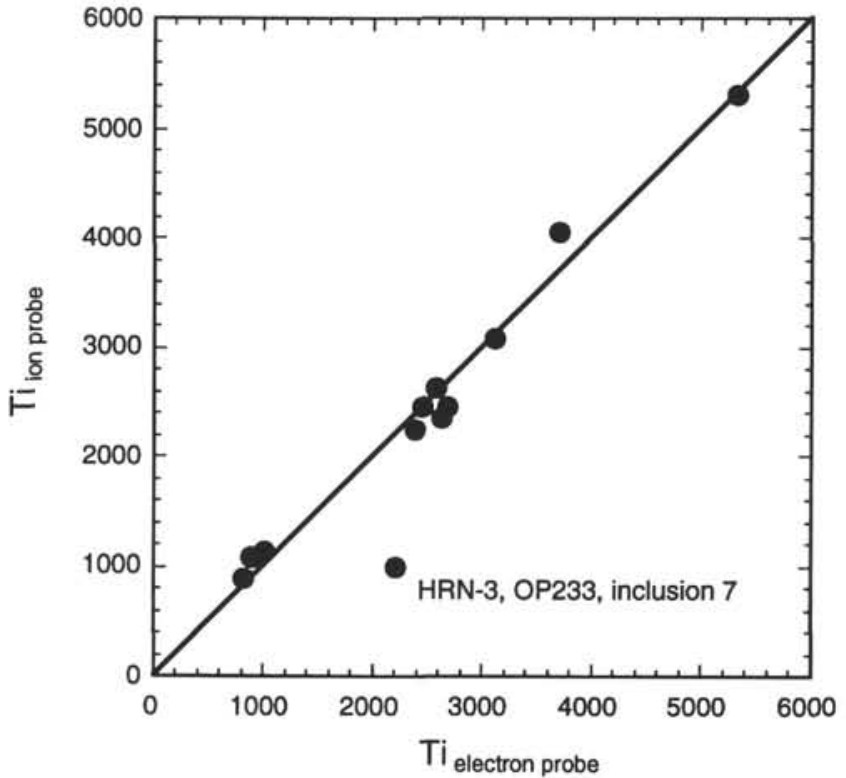

Figure 3. Comparison of $\mathrm{Ti}$ analyses by electron and ion microprobes to demonstrate agreement of the techniques. The significance of Sample HRN-3, inclusion 7 , is discussed in the text.

plagioclase relative to surrounding elements on a typical compatibility diagram (spider diagram-e.g., see Fig. 9). To represent the abundance of these two elements relative to their adjacent elements, we calculated $\mathrm{Sr}^{*}=\left(\mathrm{Ce}_{\mathrm{n}}+\mathrm{Nd}_{\mathrm{n}}\right) / 2$ and $\mathrm{Eu} *=\left(3 \mathrm{Sm}_{\mathrm{n}}+\mathrm{Dy}_{\mathrm{n}}\right) / 4$, and calculated the ratios $\mathrm{Sr} / \mathrm{Sr}^{*}$ and $\mathrm{Eu} / \mathrm{Eu}^{*}$. Values greater than unity mean that there is a positive concentration anomaly for that element. If both values are greater than one in a sample, then there is a possibility that significant beam overlap onto plagioclase occurred. As can be seen in Figure 4, two samples plot in the top right quadrant, and their compositional characteristics may be influenced by plagioclase contamination.

\section{Post-entrapment Crystallization of Host Plagioclase}

To discuss primary inclusion compositions, the extent of postentrapment interaction must be evaluated. Ways in which the inclusion composition might be altered after trapping include crystallization of the trapped melt, diffusive re-equilibration of the host phase and the melt inclusion at different pressures and temperatures than those prevailing at the time of trapping, and possible decompression melting of the host phase upon ascent. We do not expect that the pressure difference between entrapment and the surface has a significant effect on the composition of the melt inclusions, but both crystallization of the inclusion and melting of the host plagioclase will affect the composition of the inclusion.

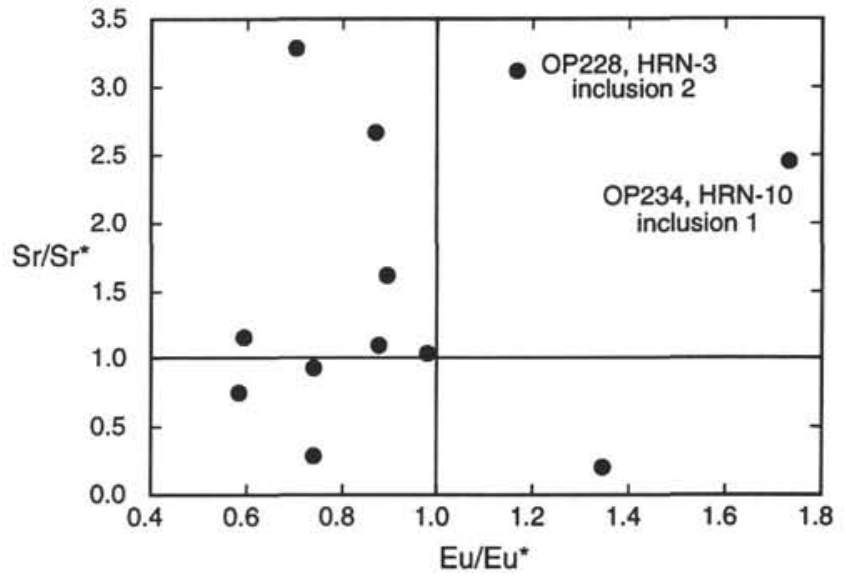

Figure $4 . \mathrm{Sr} / \mathrm{Sr}^{*}$ vs. Eu/Eu* in the melt inclusions. These values are calculated based on chondrite normalized values of these elements relative to adjacent elements in the spider diagram and are used to assess ion beam overlap from inclusion onto host plagioclase. Since both of these elements are compatible in plagioclase and their surrounding elements ( $\mathrm{Ce}$ and $\mathrm{Nd}$, and $\mathrm{Sm}$ and $\mathrm{Dy}$, respectively) are incompatible, beam overlap with plagioclase will result in a positive value for both of these ratios. Analyses of two samples, HRN-3 inclusion 2 and $\mathrm{HRN}-10$ inclusion 1 appear to be contaminated by plagioclase.

We approached the question of post-entrapment interaction between host plagioclase and trapped melt in two ways. First, we assumed that the host plagioclase was in chemical equilibrium with the melt at the time of entrapment. Compositions of the host plagioclase and melt inclusions lie along an empirically determined relationship between $\mathrm{Ca} /(\mathrm{Ca}+\mathrm{Na})$ ratio of the glass and of the plagioclase (Fig. 5; data from Falloon and Green, 1986, and Tormey et al., 1987), indicating that the rehomogenized melt inclusions from the experiments were in equilibrium with the host plagioclase. Second, melting of the host plagioclase $\left(\mathrm{An}_{85}-\mathrm{An}_{90}\right)$ from $1260^{\circ}-1280^{\circ} \mathrm{C}$ does not appear to be significant because the melting of the endmember plagioclase will increase the $\mathrm{Al}_{2} \mathrm{O}_{3}$ content of the melt about $0.25 \mathrm{wt} \%$ per ${ }^{\circ} \mathrm{C}$ above the plagioclase-olivine cotectic (Nielsen, 1988; 1990). The range of $\mathrm{Al}_{2} \mathrm{O}_{3}$ contents of the glass inclusions suggests that they were not heated more than about $10^{\circ} \mathrm{C}$ above the cotectic except for two inclusions with more than $20 \mathrm{wt} \% \mathrm{Al}_{2} \mathrm{O}_{3}$. The trace elements $\mathrm{Sr}$ and $\mathrm{Eu}$ (discussed below) also indicate that little plagioclase was incorporated into the glass inclusions.

If the inclusions contained crystals of plagioclase that were not completely melted in the microthermometry experiments, the inclusion composition would lie above the line in Figure 5. The fact that residual crystals are extremely rare and only three inclusion analyses (in the most refractory plagioclase) lie a significant distance above the line indicates that in most cases the inclusions were melted completely. 


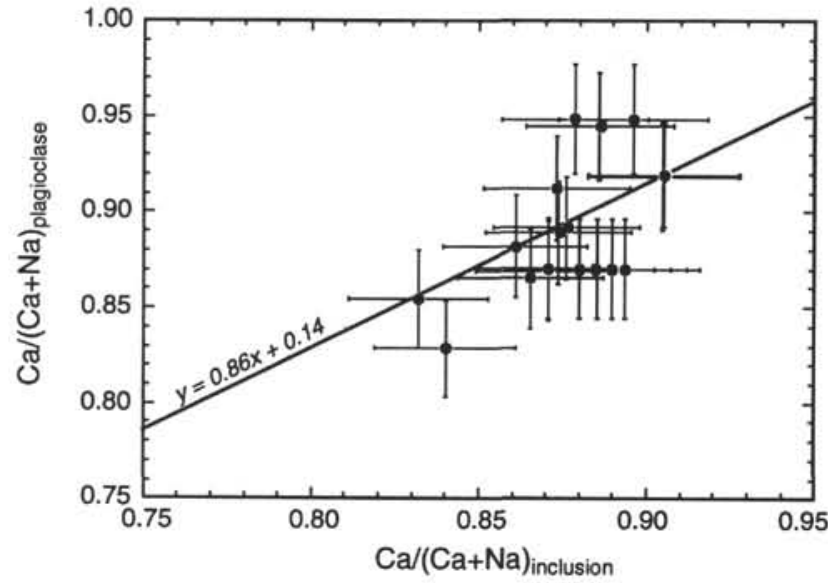

Figure $5 . \mathrm{Ca} /(\mathrm{Ca}+\mathrm{Na})$ ratios of melt inclusions vs. those of host plagioclase close to the inclusion. The line is the empirical equilibrium relationship between $\mathrm{Ca} /(\mathrm{Ca}+\mathrm{Na})$ of melts and plagioclase derived from experimental data (regression line from data in Falloon and Green [1986] and Tormey et al. [1987]). Most of the inclusions plot within analytical error (shown by error bars) of the line indicating equilibrium between host and melt.

Melt inclusions vary significantly within single plagioclase grains and from grain to grain in the same rock, making it difficult to compare experiments at different temperatures. For example, the two inclusions at $1260^{\circ} \mathrm{C}$ in Figure $6 \mathrm{~A}$ are from the same plagioclase grain. Even so, remelting of inclusions in sample $\mathrm{HRN}-3$ at $1260^{\circ}$, $1270^{\circ}$, and $1280^{\circ} \mathrm{C}$ produced relatively constant $\mathrm{Al}_{2} \mathrm{O}_{3}$ compositions with increasing temperature (Fig. 6B). We take this to mean that the most refractory melt inclusions were trapped at about $1280^{\circ} \mathrm{C}$.

\section{Major Elements}

Major element compositions of the inclusions are plotted on the plagioclase-olivine-silica face of the $\mathrm{CaO}-\mathrm{MgO}-\mathrm{Al}_{2} \mathrm{O}_{3}-\mathrm{SiO}_{2}$ (CMAS) tetrahedron using the projection scheme of Walker et al. (1979) (Fig. 7). Also plotted on the diagram are liquidus isobars drawn through 5 , 10 , and $15 \mathrm{kbar}$ experimental data points from the literature (Takahashi and Kushiro, 1983; Falloon and Green, 1987; Falloon and Green, 1988; Falloon et al., 1988; Kinzler and Grove, 1992). All of the data plot between the 5 and $10 \mathrm{kbar}$ isobars, and roughly define trends oblique to them. There does not appear to be a strong dependence on run temperature, as indicated by $\mathrm{HRN}-3$ data, but there is significant scatter in the data sets.

The range of $\mathrm{Mg}^{2+} /\left(\mathrm{Mg}^{2+}+\mathrm{Fe}^{2+}\right)$, referred to as $\mathrm{Mg} \#$, of the melt inclusions is 0.53 to 0.78 (Table 2); $\mathrm{Mg} \#$ greater than 0.70 indicates that the inclusion could have been in equilibrium with mantle olivine of $>\mathrm{Fo}_{89}$. This assumes that all iron is ferrous and the olivine-melt $\mathrm{FeO}-\mathrm{MgO}$ exchange coefficient is 0.306 (Roeder and Emslie, 1970). Table 4 summarizes the samples whose $\mathrm{Mg} /(\mathrm{Mg}+\mathrm{Fe})$ could be in equilibrium with mantle olivines.

\section{Trace Elements}

Rare earth elements in the melt inclusions are plotted in Figure 8 along with fields for basalts from Hole 504B and hypothetical melts in equilibrium with abyssal peridotites (Johnson et al., 1990; Johnson and Dick, 1992). Most of the samples show negative anomalies in $\mathrm{Zr}$ and Ti (Fig. 9), which were shown to be characteristic features in diopsides in abyssal peridotites (Johnson et al., 1990) as well as in melt inclusions from Mid-Atlantic Ridge basalts (Johnson, 1990; Sobolev and Shimizu, 1993).

\section{DISCUSSION}

The melting process at mid-ocean ridges has been modeled in many ways, but most geochemists now concur that it is an incremental pro-

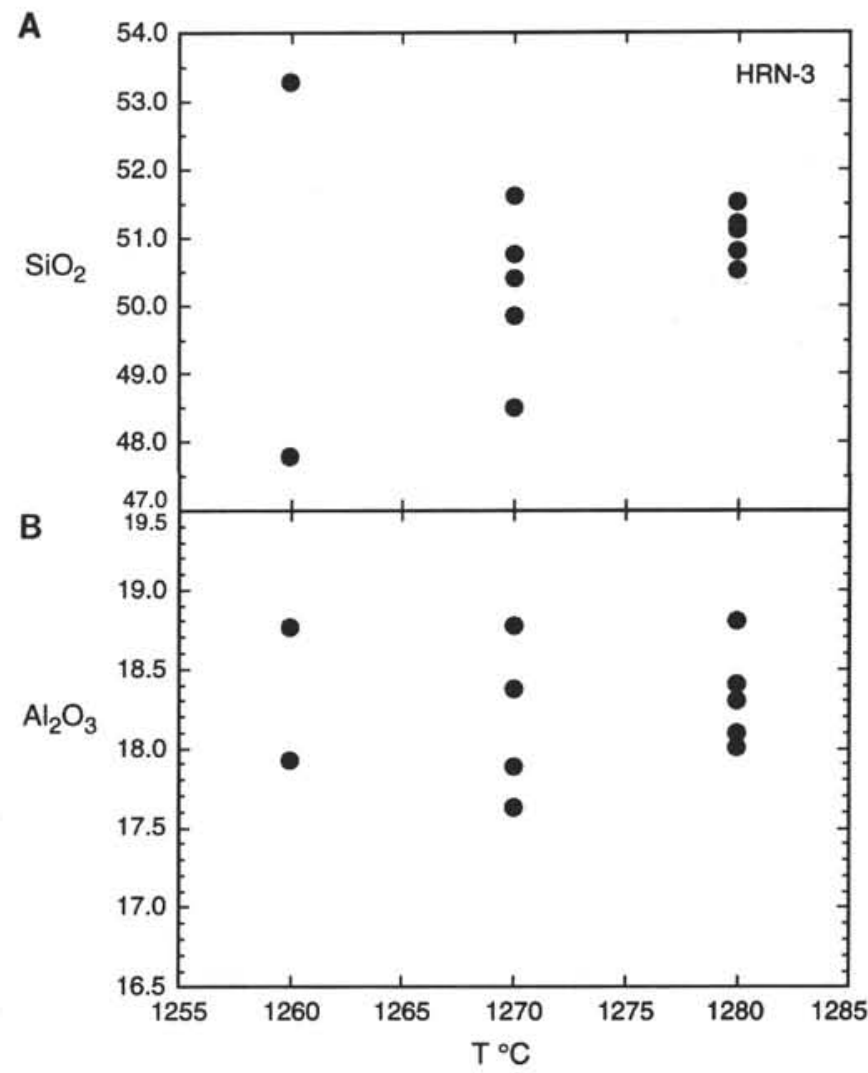

Figure 6. Change of (A) $\mathrm{SiO}_{2}$ and (B) $\mathrm{Al}_{2} \mathrm{O}_{3}$ content of melt inclusions in Sample HRN-3 with experimental run temperature. The convergence of $\mathrm{SiO}_{2}$ and the constant $\mathrm{Al}_{2} \mathrm{O}_{3}$ may mean that, while the inclusions are remelting at increasing temperatures and subsolidus devitrification products enter the melt, the host plagioclase is not melting.

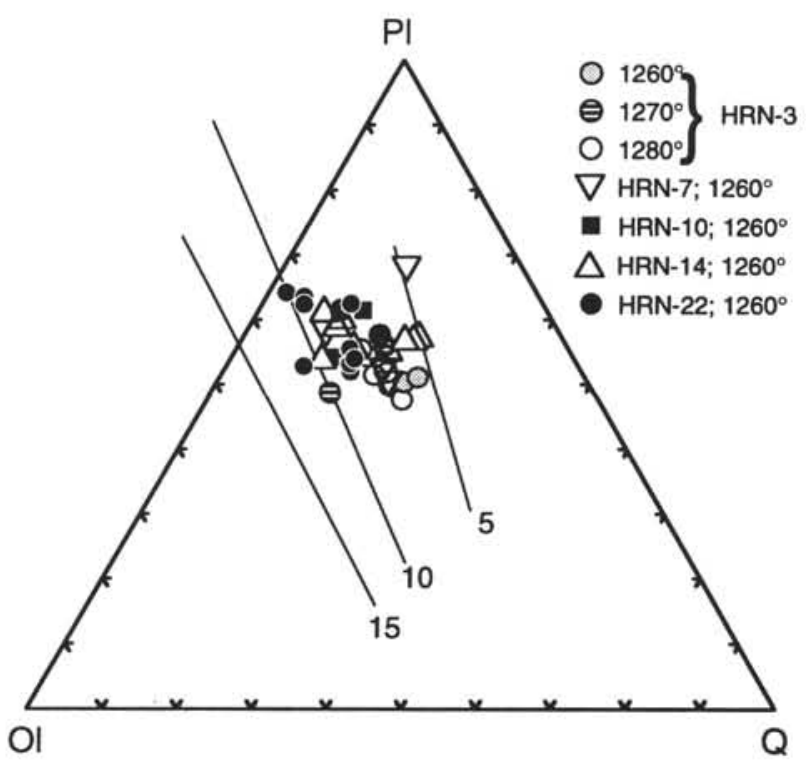

Figure 7. Plagioclase-olivine-quartz projection in the CMAS system for MORB inclusions using the projection algorithm of Walker et al. (1979). Labeled pseudocotectics at various pressures are drawn through experimental data of Takahashi and Kushiro (1983), Falloon and Green (1987, 1988), Falloon et al. (1988), and Kinzler and Grove (1992). Inclusions (symbols) define a trend oblique to the pseudocotectics, consistent with derivation by melting over a depth range from 30 to $15 \mathrm{~km}$ (10 to $5 \mathrm{~kb}$ ). 
Table 4. Measured Mg\# in melt inclusions and calculated equilibrium forsterite (Fo) contents in mantle olivine.

\begin{tabular}{lrcc}
\hline Sample & Inclusion & $\mathrm{Mg \#}_{\text {inclusion }}$ & Equilibrium Fo \\
\hline HRN-3 & 9 & 0.772 & 0.019 \\
& 10 & 0.818 & 0.937 \\
HRN-7 & 11 & 0.770 & 0.918 \\
HRN-10 & 1 & 0.785 & 0.924 \\
& 1 & 0.824 & 0.940 \\
HRN-14 & 13 & 0.856 & 0.952 \\
& 3 & 0.714 & 0.893 \\
& 4 & 0.733 & 0.901 \\
& 5 & 0.716 & 0.894 \\
HRN-22 & 7 & 0.733 & 0.901 \\
& 9 & 0.708 & 0.890 \\
& 13 & 0.711 & 0.891 \\
& 14 & 0.774 & 0.919 \\
& 15 & 0.777 & 0.921 \\
& & 0.720 & 0.896 \\
\hline
\end{tabular}

Note: $\mathrm{Mg} \#=\mathrm{Mg}^{2+} /\left(\mathrm{Mg}^{2+}+\mathrm{Fe}^{2+}\right)$.

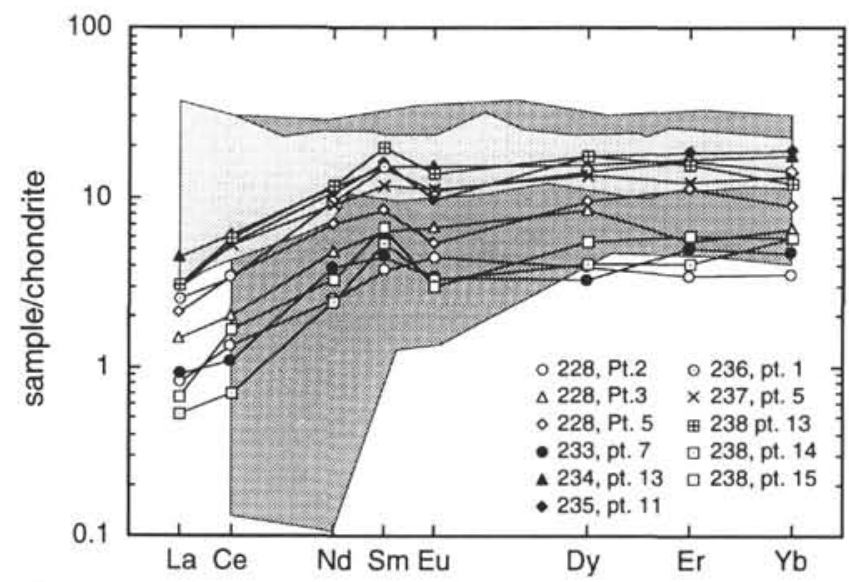

Figure 8. Chondrite normalized rare earth element concentrations in inclusions other than the two that showed both $\mathrm{Sr}$ and $\mathrm{Eu}$ anomalies in Figure 4. Lightly shaded field is the range of basalt compositions from Hole 504B showing that the majority of the inclusions are more depleted than the host basalts. The field for hypothetical liquids in equilibrium with abyssal peridotite diopsides (Johnson et al., 1990) is shown in heavy shading. Assuming that the peridotites represent the final residue of melting at the top of the mantle melting column, liquids in equilibrium with those rocks should be extremely depleted in incompatible elements, while MORB plot outside this field. Many of the inclusions plot in the lower portion of the field.

cess with the generation and nearly simultaneous removal of small melt fractions (Langmuir et al., 1977; Maaløe, 1982; McKenzie, 1985; Rubin and Macdougall, 1988; Johnson et al., 1990; Johnson and Dick, 1992; Sobolev and Shimizu, 1993). While the models differ in detail, they are similar in that melt is efficiently removed from the system soon after formation with only small amounts retained in the residue at any one time. The model we employ in this paper, opensystem melting (Johnson and Dick, 1992), allows for melt formation, then rapid and efficient segregation and flow through overlying peridotites. Thus, the source for melting is peridotite + melt-from-below at all times, and the model allows for a melting column open at the bottom to infusion of melts. Using the open-system model, the amount of transiently retained melt in mid-ocean-ridge settings, based on trace element concentrations in peridotites, ranges from $0.2 \%$ to $3.0 \%$ (Johnson and Dick, 1992). This range implies segregation of very small melt fractions, nearly fractional melting in many cases.

If sub-ridge melting involves such small melt fractions, then it follows that late-stage, highly depleted, refractory melts must exist
A

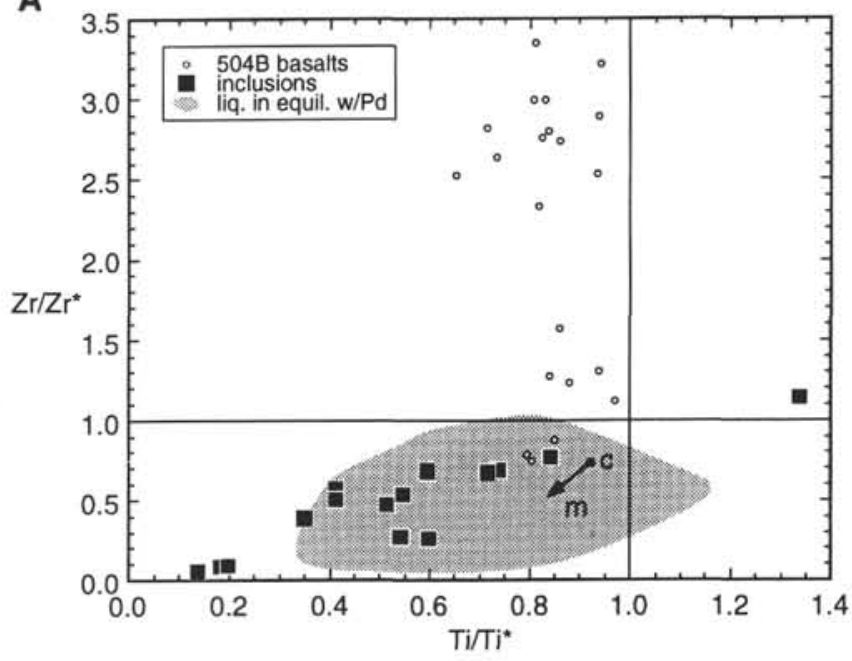

B

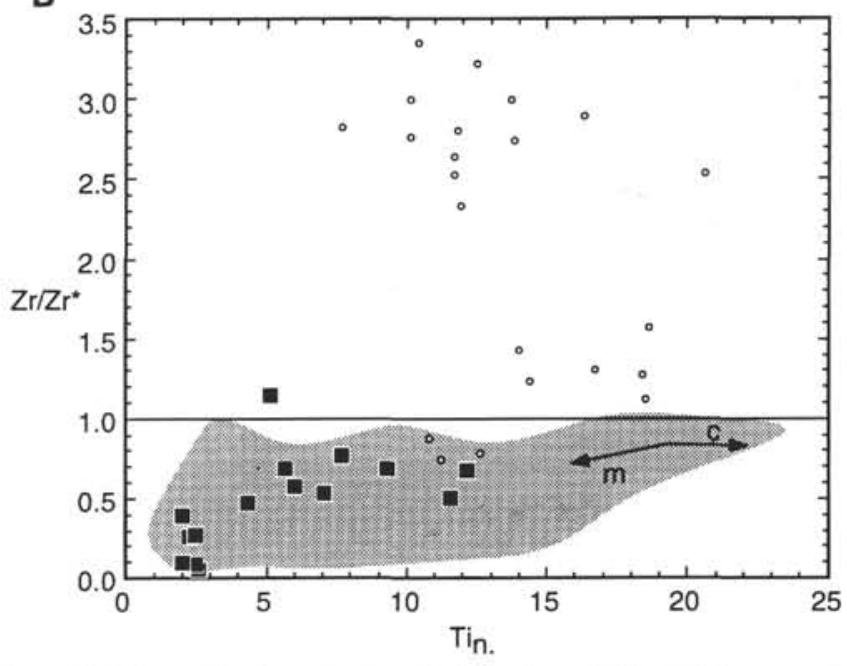

Figure 9. A. Anomalies in non-rare earth trace elements $\mathrm{Zr}$ and $\mathrm{Ti}$ expressed as the ratios of chondrite-normalized $\mathrm{Zr}$ and $\mathrm{Ti}$ to interpolated value of these elements between the closest analyzed rare earth elements on an incompatibility (spider) diagram. B. Change in $\mathrm{Zr} / \mathrm{Zr}$ * with $\mathrm{Ti}$ used as a relative measure of crystal fractionation or melting. $\mathrm{Zr} *$ is calculated as $\left(\mathrm{Nd}_{\mathrm{n}}+\mathrm{Sm}_{\mathrm{n}}\right) / 2$ and $\mathrm{Ti}^{*}$ is calculated as $\left(3 \mathrm{Sm}_{n}+5 \mathrm{Dy}_{n}\right) / 8$. Thus, $\mathrm{Zr} / \mathrm{Zr}^{*}$ and $\mathrm{Ti} / \mathrm{Ti}^{*}$ are measures of the anomalies of these elements on spider diagrams, with values less than 1 indicating negative anomalies, which can be seen in most of the inclusions. Shaded field represents hypothetical melts in equilibrium with abyssal peridotite diopsides (Johnson et al., 1990; Johnson and Dick, 1992). If the peridotites represent the final residue of melting over a melting column, then the inclusion compositions are consistent with their being the complementary melt increments from this process. Arrows marked " $\mathrm{m}$ " and "c" are the trajectories expected for fractional melt increments and crystallization, respectively. Normalizing values from Anders and Grevesse (1989).

between the point of magma segregation and the region of aggregation and final mixing prior to eruption as MORB. Such melts are a necessary consequence of low melt retention open-system melting, and their recognition is of critical importance in understanding processes of MORB petrogenesis in general, and in evaluating the validity of the open-system melting model in particular. These melts will rarely reach the surface unaffected by mixing, making their existence difficult to directly document. However, minerals growing in a magma occasionally trap small drops of melt on their growing surface or in their skeletal interiors (Roedder, 1984) and preserve them as melt inclusions, more or less unaffected by external processes. 


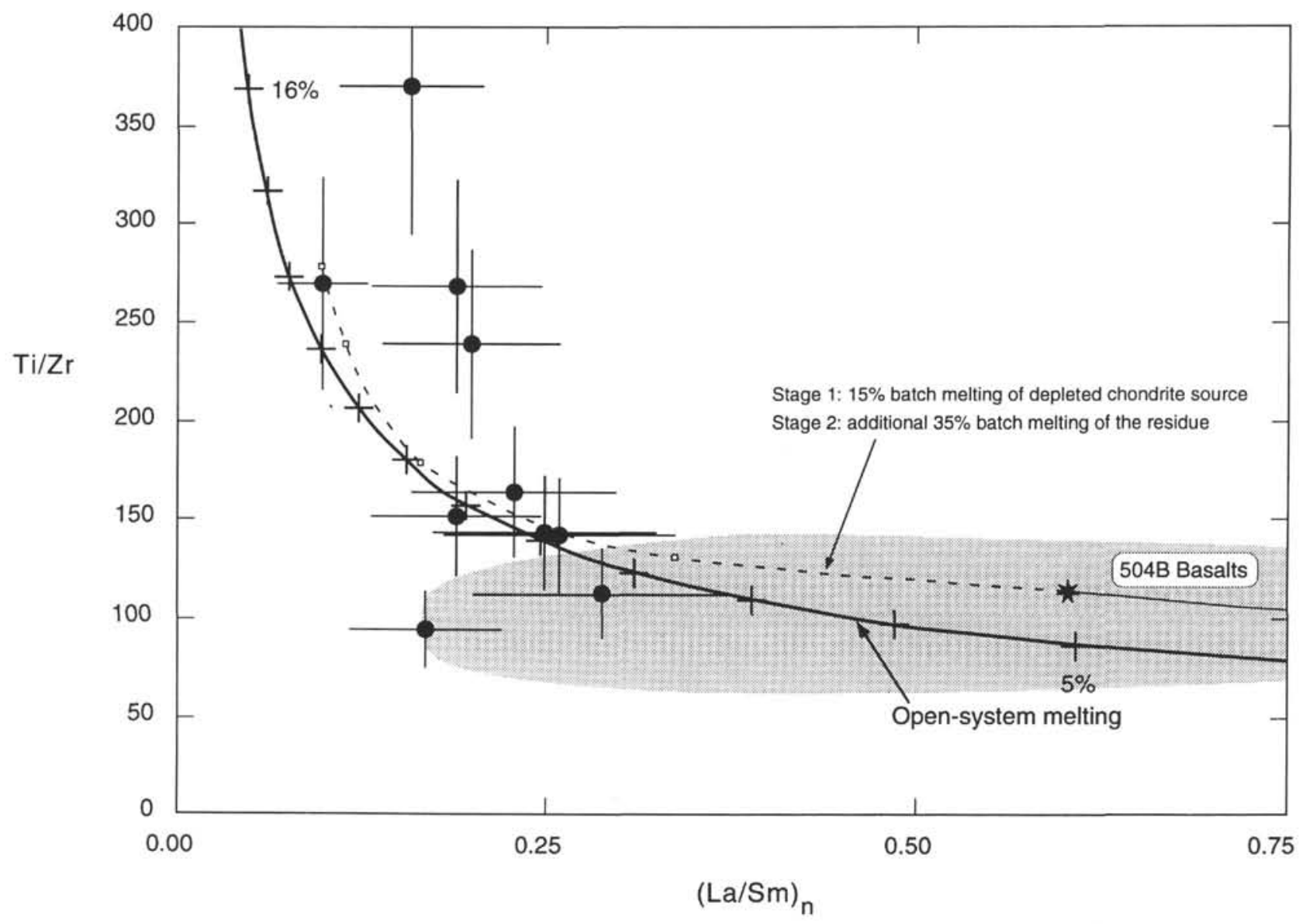

Figure 10. Inclusion compositions in terms of $\mathrm{Ti} / \mathrm{Zr}$ and $(\mathrm{La} / \mathrm{Sm})_{n}$. The open system melt model discussed in the text is plotted as the solid curve with pluses every one percent melting using the parameters in Table 5 . The dashed curve is the second stage of a two-stage batch melting process after an initial $15 \%$ batch melting (star symbol); square symbols are at 5\% melt intervals. Most of the inclusions plot outside the field of 504B basalts and are consistent with $8 \%-16 \%$ open-system melting with a constant $2 \%$ melt retained in the residue throughout the melting event.

Trace element concentrations in the melt inclusions are generally more depleted than associated basalts from Hole 504B (Figs. 8 and 9). Furthermore, the inclusions display large negative anomalies in $\mathrm{Ti}$ and $\mathrm{Zr}$, which are uncommon in 504B basalts (Fig. 9A). Although the inclusions are more depleted than associated basalts, they lie within the range of values for melts in equilibrium with diopsides from abyssal peridotites (Figs. 8 and 9). Assuming that the peridotites represent the final residue of melting over a melting column, the inclusion compositions are consistent with their being the complementary melt increments from this process. Furthermore, the inclusions cannot be related to most of the analyzed 504B basalts by simple crystal fractionation ("c" in Fig. 9).

\section{Melting Model}

$\mathrm{Ti} / \mathrm{Zr}$ ratios in MORB are generally between 80 and 125 . This range is roughly centered about the chondritic ratio of $\sim 110$ and is consistent with the hypothesis that MORB represent aggregated melts produced by incremental melting of the mantle. Trace element concentrations in abyssal peridotites (Johnson et al., 1990) argue against the former process. During fractional melting, individual melt fractions will not be constrained to asymptotically approach the $\mathrm{Ti} / \mathrm{Zr}$ ratio of their source, as will batch and integrated melts, but instead will reach much higher values, the limit being infinity for advanced increments of perfect fractional fusion. This means that $\mathrm{Ti} / \mathrm{Zr}$ ratios in both incremental or fractional melts and their residues can increase to greater than the ratio in their source as fractional melting proceeds.
If the upper mantle source for MORB has a roughly chondritic $\mathrm{Ti} / \mathrm{Zr}$ ratio, then melts with $\mathrm{Ti} / \mathrm{Zr} \gg$ chondritic could be produced from a source that has been depleted by varying degrees of open-system melting. To evaluate the inclusion compositions reported here in light of this model, we have plotted $\mathrm{Ti} / \mathrm{Zr}$ vs. $(\mathrm{La} / \mathrm{Sm})_{n}$ in the melt inclusions in Figure 10. Also plotted are theoretical curves calculated using the open-system model presented by Johnson and Dick (1992) and Johnson and Kong (1992) using the parameters listed in Table 5 and a constant $2 \%$ porosity. The data fall outside of the generalized field for MORB to more depleted compositions. Batch melting to $30 \%$ defines a trajectory terminating in the MORB field, but open-system melting with a $2 \mathrm{wt} \%$ melt fraction present in the source (which may be thought of as a constant mantle porosity) produces a trend shown by the solid line in Figure 10. Even if a two-stage batch melting process is envisioned (dashed curve in Fig. 10), with an initial stage of $15 \%$ melting followed by melt removal and then an additional $35 \%$ batch melting of the residue for a total of $50 \%$ melting, the most extreme inclusion compositions cannot be produced. Thermal conditions in a normal mid-ocean spreading environment do not permit melting much beyond a total of $25 \%-30 \%$ due to the increase in solidus temperature when clinopyroxene disappears from the assemblage.

Melting of a peridotite mantle will produce magmas varying in composition with percent melting as well as with pressure (Kushiro, 1969, 1972; Jaques and Green, 1980; Takahashi and Kushiro, 1983; Falloon and Green, 1987). With increasing pressure, melts become less silica-rich, but conform to pseudocotectic curves in the CMAS projections that are subparallel to each other. In a general sense, the 
Table 5. Parameters used in melting model.

\begin{tabular}{lllllr}
\hline & Cpx & \multicolumn{1}{c}{ Ol } & \multicolumn{1}{c}{ Opx } & \multicolumn{1}{c}{ Sp } & \multicolumn{1}{c}{$\mathrm{C}_{\mathrm{o}}$} \\
\hline $\mathrm{D}_{\mathrm{Ti}}$ & 0.36 & 0.008 & 0.08 & 0.07 & 872 \\
$\mathrm{D}_{\mathrm{Zr}}$ & 0.15 & 0.003 & 0.02 & 0.04 & 7.1 \\
$\mathrm{D}_{\mathrm{La}}$ & 0.05 & 0.00001 & 0.008 & 0.0008 & 1.0 \\
$\mathrm{D}_{\mathrm{Ce}}$ & 0.1 & 0.00005 & 0.01 & 0.0008 & 1.2 \\
$\mathrm{D}_{\mathrm{Nd}}$ & 0.17 & 0.0001 & 0.02 & 0.0008 & 1.6 \\
$\mathrm{D}_{\mathrm{Sm}}$ & 0.28 & 0.0007 & 0.03 & 0.0009 & 2.0 \\
$\mathrm{D}_{\mathrm{Eu}}$ & 0.34 & 0.001 & 0.04 & 0.009 & 2.1 \\
$\mathrm{D}_{\mathrm{Dy}}$ & 0.43 & 0.004 & 0.06 & 0.0015 & 2.2 \\
$\mathrm{D}_{\mathrm{Er}}$ & 0.42 & 0.007 & 0.1 & 0.0045 & 2.3 \\
$\mathrm{D}_{\mathrm{Yb}}$ & 0.42 & 0.009 & 0.12 & 0.0045 & 2.3 \\
$\mathrm{X}$ & 0.16 & 0.56 & 0.24 & 0.04 & \\
$\mathrm{p}$ & 0.67 & -0.10 & 0.38 & 0.05 & \\
\hline
\end{tabular}

Notes: $\mathrm{Cpx}=$ clinopyroxeene; $\mathrm{Ol}=$ olivine; $\mathrm{Opx}=$ orthopyroxene $\mathrm{Sp}=$ spinel; $\mathrm{C}_{\mathrm{o}}=$ starting source composition. $\mathrm{X}=$ starting mode in the source modified from Johnson et al (1990). $\mathrm{p}=$ proportions of minerals entering melt derived using experimental data from Takahashi and Kushiro (1983), Falloon and Green (1987, 1988), Falloon et al (1988), and Kinzler and Grove (1992). Sources of partitioning data: Clinopyroxene: Johnson and Kinzler (1989), Hart and Dunn (1993), K. Johnson (unpubl. data). Olivine, opx: REE, Stosch [1982], combined with cpx partition coefficients, McKay (1986). Ti, Zr, Sr, Fujimaki et al. (1984), Weill and McKay (1975), McKay and Weil (1977). Spinel: REE, Stosch (1982), combined with cpx partition coefficients. Ti, Zr, $\mathrm{K}$. Johnson, Ti calculated from electron probe data; $\mathrm{Zr}$ estimated from secondary ion counts relative to cpx. Garnet: REE, Shimizu and Kushiro (1975), Nicholls and Harris (1980), Fujimaki et al. (1984). Ti, Zr, Sr, Fujimaki et al. (1984), Green et al. (1989). Plagioclase: $\mathrm{Zr}, \mathrm{Sr}$, Drake and Weill (1975), Fujimaki et al. (1984).

data in Figure 7 define a trend that intersects the isobars from 10 to 5 kilobars. We interpret this trend as representing polybaric melting and entrapment of individual instantaneous melt fractions during magma ascent beneath the ocean ridge. A similar trend was identified in a suite of melt inclusions from the North Atlantic Ocean by Sobolev and Shimizu (1993).

\section{SUMMARY AND CONCLUSIONS}

The data and melting model presented suggest that the melt inclusions in plagioclase from diabases in hole 504B represent trapped primitive or primary magmas. This is supported by $\mathrm{Mg}$ numbers that could have been in equilibrium with mantle olivines and by trace element models indicating late-stage derivation by open-system melting of a slightly REE-depleted peridotite source with about $2 \%$ melt retained in the source. These magmas were formed during pressure-release melting of the mantle over a range of depths between 30 and 15 $\mathrm{km}$ and represent small melt fractions produced by a near-fractional, open-system melting process.

The data suggest that magma evolution must be a complex process that starts as soon as melts segregate from their source. We speculate that mixing between melt increments from different sources can occur in channels, conduits, or veins at any point in the ascending mantle after segregation takes place, but that equilibration between these melt increments and the surrounding residual mantle must be minimal. Thus, extremely depleted compositions can be trapped as melt inclusions in growing mineral phases before homogenization of the diverse melt fractions prior to eruption. This study demonstrates that silicate melt inclusions can be useful in gaining insights into melting processes that complement those provided by abyssal peridotites.

\section{REFERENCES}

Anders, E., and Grevesse, N., 1989. Abundances of the elements: meteoritic and solar. Geochim. Cosmochim. Acta, 53:197-214.

\footnotetext{
- Abbreviations for names of organizations and publications in ODP reference lists follow the style given in Chemical Abstracts Service Source Index (published by American Chemical Society).
}

Bender, J.F., Langmuir, C.H., and Hanson, G.N., 1984. Petrogenesis of basalt glasses from the Tamayo region, East Pacific Rise. J. Petrol., 25:213-254.

Coombs, V.L., Nielsen, R.L., Sinton, C.W., and Christie, D.M., 1991. The nature of the parent magma of high anorthite megacrysts from the Galapagos Platform. Eos, 72:579.

Dick, H.J.B., Fisher, R.L., and Bryan, W.B., 1984. Mineralogic variability of the uppermost mantle along mid-ocean ridges. Earth Planet. Sci. Lett., 69:88-106

Donaldson, C.H., and Brown, R.W., 1977. Refractory megacrysts and magnesium-rich melt inclusions within spinel in oceanic tholeiites: indications of magma mixing and parental magma composition. Earth Sci. Planet. Lett., 37:81-89.

Drake, M.J., and Weill, D.F., 1975. Partition of $\mathrm{Sr}, \mathrm{Ba}, \mathrm{Ca}, \mathrm{Y}, \mathrm{Eu}^{2+}, \mathrm{Eu}^{3+}$, and other REE between plagioclase feldspar and magmatic liquid: an experimental study. Geochim. Cosmochim. Acta, 39:689-712.

Dungan, M.A., and Rhodes, J.M., 1978. Residual glasses and melt inclusions in basalts from DSDP Legs 45 and 46: evidence for magma mixing. Contrib. Mineral. Petrol., 67:417-431.

Falloon, T.J., and Green, D.H., 1986. Glass inclusions in magnesian olivine phenocrysts from Tonga: evidence for highly refractory parental magmas in the Tonga arc. Earth Planet. Sci. Lett., 81:95-103.

, 1987. Anhydrous partial melting of MORB pyrolite and other peridotite compositions at $10 \mathrm{kbar}$ : implications for the origin of primitive MORB glasses. Mineral. Petrol., 37:181-219.

- 1988. Anhydrous partial melting of peridotite from 8 to $35 \mathrm{~kb}$ and the petrogenesis of MORB. J. Petrol. Spec. Lithosphere Iss., 379-414.

Falloon, T.J., Green, D.H., Hatton, C.J., and Harris, K.L., 1988. Anhydrous partial melting of a fertile and depleted peridotite from 2 to $30 \mathrm{~kb}$ and application to basalt petrogenesis. J. Petrol., 29:1257-1282.

Forsythe, L.M., and Fisk, M.R., 1993. Comparison of experimentally crystallized and natural spinels from Leg 135. In Hawkins, J., Parson, L., Allan, J., et al., Proc. ODP, Sci. Results, 135: College Station, TX (Ocean Drilling Program), 585-594.

Fujimaki, H., Tatsumoto, M., and Aoki, K., 1984. Partition coefficients of Hf, $\mathrm{Zr}$, and REE between phenocrysts and groundmass. Proc. Lunar Planet. Sci. Conf., 14th (Part 2). J. Geophys. Res., 89 (Suppl.):B662-B672.

Green, T.H., Sie, S.H., Ryan, C.G., and Cousens, D.R., 1989. Proton microprobe-determined partitioning of $\mathrm{Nb}, \mathrm{Ta}, \mathrm{Zr}, \mathrm{Sr}$ and $\mathrm{Y}$ between garnet, clinopyroxene and basaltic magmas at high pressure and temperature. Chem. Geol., 74:201-216.

Hansteen, T.H., 1991. Multi-stage evolution of the picritic Maelifell rocks, SW Iceland: constraints from mineralogy and inclusions of glass and fluid in olivine. Contrib. Mineral. Petrol., 109:225-239.

Hart, S.R., and Dunn, T., 1993. Experimental CPX/melt partitioning of 24 trace elements. Contrib. Mineral. Petrol., 113:1-8.

Jaques, A.L., and Green, D.H., 1980. Anhydrous melting of peridotite at 0-15 $\mathrm{kb}$ pressure and the genesis of the tholeiitic basalts. Contrib. Mineral. Petrol., 73:287-310.

Jarosewich, E., Nelen, J.A., and Norberg, J.A., 1980. Reference samples for electron microprobe analysis. Geostand. Newslett., 4:43-47.

Johnson, K.T.M., 1990. Trace element geochemistry of oceanic peridotites and silicate melt inclusions: implications for mantle melting and ocean ridge magmagenesis [Ph.D. dissert.]. Massachusetts Institute of Technology/Woods Hole Oceanographic Institution, Cambridge, MA.

Johnson, K.T.M., and Dick, H.J.B., 1992. Open system melting and temporal and spatial variation of peridotite and basalt at the Atlantis II Fracture Zone. J. Geophys. Res., 97:9219-9241.

Johnson, K.T.M., Dick, H.J.B., and Shimizu, N., 1990. Melting in the oceanic upper mantle: an ion microprobe study of diopsides in abyssal peridotites. J. Geophys. Res., 95:2661-2678.

Johnson, K.T.M., and Kinzler, R.J., 1989. Partitioning of REE, Ti, Zr, Hf, and $\mathrm{Nb}$ between clinopyroxene and basaltic liquid: an ion microprobe study. Eos, 70:1388.

Johnson, K.T.M., and Kong, L.S.L., 1992. Open system melting at mid-ocean ridges. Eos, 73:615.

Kinzler, R.J., and Grove, T.L., 1992. Primary magmas of mid-ocean ridge basalts: experiments and methods. J. Geophys. Res., 97:6885-6906.

Klein, E.M., and Langmuir, C.H., 1987. Global correlations of ocean ridge basalt chemistry with axial depth and crustal thickness. J. Geophys. Res., 92:8089-8115.

Kushiro, I., 1969. The system forsterite-diopside-silica with and without water at high pressures. Am. J. Sci., 267A:269-294.

1972. The effect of water on the composition of magmas formed at high pressures. J. Petrol., 13:311-334. 
Langmuir, C.H., Bender, J.F., Bence, A.E., and Hanson, G.N., 1977. Petrogenesis of basalts from the FAMOUS area: Mid-Atlantic Ridge. Earth Planet. Sci. Lett., 36:133-156.

Maaløe, S., 1982. Geochemical aspects of permeability controlled partial melting and fractional crystallization. Geochim. Cosmochim. Acta, 46:43-57.

McKay, G.A., 1986. Crystal/liquid partitioning of REE in basaltic systems: extreme fractionation of REE in olivine. Geochim. Cosmochim. Acta, 50:69-79.

McKay, G.A., and Weill, D.F., 1977. KREEP petrogenesis revisited. Proc. 8th Lunar Sci. Conf., 2339-2355.

McKenzie, D., $1985 .{ }^{230} \mathrm{Th}^{238} \mathrm{U}$ disequilibrium and the melting processes beneath ridge axes. Earth Planet. Sci. Lett., 72:149-157.

McKenzie, D., and Bickle, M.J., 1988. The volume and composition of melt generated by extension of the lithosphere. J. Petrol., 29:625-679.

Nicholls, I.A., and Harris, K.L., 1980. Experimental rare earth element partition coefficients for garnet, clinopyroxene, and amphibole coexisting with andesitic and basaltic liquids. Geochim. Cosmochim. Acta, 44:287-308.

Nielsen, R.L., 1988. A model for the simulation of combined major and trace element liquid lines of descent. Geochim. Cosmochim. Acta, 52:27-38.

, 1990. Simulation of igneous differentiation processes. In Nicholls, J., and Russell, J.K. (Eds.), Modern Methods of Igneous Petrology: Understanding Magmatic Processes. Mineral. Soc. Am., Rev. Mineral., 24:65-105.

Riley, G.N., and Kohlstedt, D.L., 1991. Kinetics of melt migration in upper mantle-type rocks. Earth Planet. Sci. Lett., 105:500-521.

Roedder, E., 1984. Fluid inclusions. Rev. Mineral., Mineral. Soc. Am., 12.

Roeder, P.L., and Emslie, R.F., 1970. Olivine-liquid equilibrium. Contrib. Mineral. Petrol., 29:397-410.

Rubin, K.H., and Macdougall, J.D., 1988. ${ }^{226} \mathrm{Ra}$ excesses in mid-ocean ridge basalts and mantle melting. Nature, 335:158-161.

Shimizu, N., and Kushiro, I., 1975. The partitioning of rare earth elements between garnet and liquid at high pressures: preliminary experiments. Geophys. Res. Lett., 2:413-416.

Sinton, C.W., Christie, D.M., Coombs, V.L., Nielsen, R.L., and Fisk, M.R. 1993. Near-primary melt inclusions in anorthite phenocrysts from the Galapagos Platform. Earth Planet. Sci. Lett. 119:527-538.
Sobolev, A.V., and Dmitriev, L.V., 1989. Primary melts of tholeiites of oceanic rifts (TOR): evidence from studies of primitive glasses and melt inclusions in minerals. Int. Geol. Congr., 3:147-148. (Abstract)

Sobolev, A.V., and Naumov, V.B., 1985. First direct proof of the presence of water in ultramafic melts and their estimated water content. Geochem. Int., 10:102-105.

Sobolev, A.V., and Shimizu, N., 1993. Ultra-depleted primary melt included in an olivine from the Mid-Atlantic Ridge. Nature, 363:151-154.

Stosch, H.-G., 1982. Rare earth element partitioning between minerals from anhydrous spinel peridotite xenoliths. Geochim. Cosmochim. Acta, 46:793-811.

Takahashi, E., and Kushiro, I., 1983. Melting of a dry peridotite at high pressures and temperatures and basalt magma genesis. Am. Mineral., 68:859-879.

Tormey, D.R., Grove, T.L., and Bryan, W.B., 1987. Experimental petrology of normal MORB near the Kane Fracture Zone: $22^{\circ} 25^{\circ} \mathrm{N}$, mid-Atlantic Ridge. Contrib. Mineral. Petrol., 96:121-139.

Vicenzi, E., 1985. The geology, petrology and petrogenesis of Isle Marchena, Galapagos Archipelago [M.S. thesis]. Univ. Oregon, Eugene.

Waff, H.S., and Faul, U.H., 1992. Effects of crystalline anisotropy on fluid distribution in ultramafic partial melts. J. Geophys. Res., 97:9003-9014.

Walker, D., Shibata, T., and Delong, S.E., 1979. Abyssal tholeiites from the Oceanographer Fracture Zone, II: Phase equilibria and mixing. Contrib. Mineral. Petrol., 70:111-125.

Weill, D.F., and McKay, G.A., 1975. The partitioning of Mg, Fe, Sr, Ce, Sm, $\mathrm{Eu}$, and $\mathrm{Yb}$ in lunar igneous systems and a possible origin of KREEP by equilibrium partial melting. Proc. 6th Lunar Sci. Conf., 1143-1158.

Date of initial receipt: 28 May 1993

Date of acceptance: 14 April 1994

Ms 137/140SR-004 